\title{
Influence of Organic Fertilizers on Physiological Quality and Rooting of Snapdragons (Antirrhinum majus)
}

\author{
Mustafa Demirkaya ${ }^{1 *}$, Werner Stumpf ${ }^{2}$ and Karoline Jezik ${ }^{2}$ \\ ${ }^{1}$ Department of Agriculture, Safiye Cikrikcioglu Vocational College, Erciyes University, 38039, Kayseri, Turkey \\ ${ }^{2}$ Department of Crop Sciences, Division of Vegetables and Ornamentals, University of Natural Resources and Life Sciences, \\ Gregor-Mendel-Strasse 33, 1180, Vienna, Austria \\ *For correspondence: mustafad@erciyes.edu.tr
}

\begin{abstract}
In this study, the effects of organic fertilizers on internal quality and rooting of snapdragons (Antirrhinum majus) were investigated. Seedlings of 'White Rocket', 'Rocket Gold', 'Orchid', 'Red Stone' and 'Red Rocket' species were transplanted into $12 \mathrm{~L}$ pots filled with 1:1 sand: soil mixture at the beginning of March 2011. Two different liquid biological fertilizers were used. The first one is the Effective Microorganisms $\left(\mathrm{EM}^{\circledR}\right)$ consisting of lactic acid bacteria (Lactobacillus casei and Lactobacillus plantarum), photosynthesis bacteria (Rhodopseudomonas palustris) and fermentation bacteria (Saccharomyces cervisiae); the second one is Rhizo Vital $42^{\circledR}$ consisting of Bacillus amyloliquefaciens bacteria. The physiological quality of the petals was investigated. With regard to petal P-dissipation values, while EM treatments yielded almost identical results with the control treatment, Rhizo Vital 42 treatments had lower yield values than the control treatment. Both organic fertilizer treatments improved rooting and effects of EM treatments on rooting were found to be significant. Biophoton measurements were also performed over the petals and photoluminescence values of fertilizer treatments of all species were found to be lower than the control plants. In other words, organic fertilizer treatments improved the quality by decreasing the stress levels in petals. (C) 2016 Friends Science Publishers
\end{abstract}

Keywords: Dissipation value; Biophoton emission; Effective microorganisms; Rhizo Vital 42

\section{Introduction}

There are different microorganisms exist like bacteria and fungi from which normally developing plants are not affected. However, there are also some bacteria and fungi that can cause diseases. Moreover, there are different species of bacteria and fungi that stimulate plant development and health (Jezik et al., 2011).

Since intensive agricultural practices may result in various environmental problems, organic farming practices are getting more and more popular nowadays. Thus, biofertilizers are commonly recommended instead of synthetic fertilizers (Karakurt et al., 2011). Plant growth promoting rhizobacteria (Bacillus species) are also commonly used to promote plant growth and development (Priest et al., 1987).

\section{Effective Microorganisms (EM)}

The EM of the present study is a commercial organic fertilizer containing regenerative microorganisms. Microorganisms enable a suitable environment for fermentation and play an important role in plant quality and soil productivity. Fermentative fragmentation is stimulated by the cease of decomposition. That means edible microorganisms exist on the soil, optimum results can be extracted, diseases can be prevented and high quality products can be produced. Over all, EM generally works in anaerobic areas in which the problems such as decomposing, putrefaction etc. appear. Thus, they can be used in anaerobic areas more efficiently. EM can be used to revive the soil, increase soil fertility and remove odor, increase the soil temperature, clean water etc. Microorganisms can be used in all areas of life. When EM have no other tasks, it is not difficult for pathogens to disappear. It is also easy to remove EM from the soil through negative signals (Lorch, 2010).

EM consists of lactic acid bacteria (Lactobacillus casei and Lactobacillus plantarum), photosynthesis bacteria (Rhodopseudomonas palustris) and fermentation bacteria (Saccharomyces cervisiae). EM do not include any genetically modified organisms. Following the preparation, it must be used in a week (Jezik et al., 2011).

\section{Rhizo Vital 42 - Bacillus Amyloliquefaciens FZB 42}

These bacteria exist in close vicinity of the roots. There are several types of these microorganisms and they are called 
rhizosphere microorganisms. The best known example is a fungus called Mycorrhiza. Another kind is Bacillus amyloliquefaciens (Kilian and Raupach, 1999). Bacillus amyloliquefaciens Rhizo Vital 42, which has antimicrobial activity, can produce a secondary change by high capacity and it strengthens the plant as a gram-positive bacterium (Chen et al., 2007). The plant root-colonizing-strain Bacillus amyloliquefaciens FZB 42 is an environmental strain which is distinguished from the domesticated model organism Bacillus subtilis 168 by its ability to stimulate plant growth and to suppress plant pathogenic organisms (Idriss et al., 2002). FZB 42 genome analysis revealed the presence of numerous gene clusters involved in the synthesis of nonribosomal synthesized cyclic lipopeptides (Koumoutsi et al., 2004) and polyketides (Chen et al., 2006; Schneider et al., 2007) with distinguished antimicrobial action.

The present study was conducted to investigate the effects of Rhizo vital 42 and effective microorganism treatments on internal quality of petals and rooting of 5 different snapdragon varieties.

\section{Materials and Methods}

\section{Experimental Details and Treatments}

Experimental material: Experiments were carried out in Jedlersdorf in the gardens of the University of Natural Resources and Life Sciences. Jedlersdorf, which lies at a sea level of $162 \mathrm{~m}$, has a precipitation of around $550 \mathrm{~mm} / \mathrm{year}$ and an average temperature of $9.8^{\circ} \mathrm{C}$. The sun shines hours are 1800 hours/year. The climate is dry, warm and windy with a yearly average of $3.2 \mathrm{~m} / \mathrm{s}$ (Jezik et al., 2010). The experiments consisted of 12 plots and each plot consisted of 5 rows (varieties) with 6 pots (replications). Four plots were treated with EM, 4 plots with Rhizo Vital 42 and 4 plots were used for monitoring as control without any treatments.

Treatments: To reduce the impacts of the surroundings, a boundary area of snapdragons (A. majus) was set up. To suppress weeds, thick black mulching was laid out on the ground of whole experimental area. At the beginning of March 2011, 5 different varieties of snapdragon seeds were sown in viols. The varieties were 'White Rocket' (white), 'Rocket Gold' (yellow), 'Orchid' (purple), 'Red Stone' (light-red) and 'Red Rocket' (dark-red). Germination took 2 weeks at a temperature of $15-20^{\circ} \mathrm{C}$. At the end of March 2011, the seedlings were transplanted to $12 \mathrm{~L}$ pots filled with a compost-sand mixture in the ratio of $1: 1$ at beginning of May 2011. Organic fertilizers (EM and Rhizo Vital 42) were applied to the plant pots at the following doses: initially a $10 \mathrm{~L}$ pitcher was half-filled with tap water, then $10 \mathrm{ml}$ EM was collected with a syringe, injected into the pitcher and stirred with a wooden stick. Water was added to fill the pitcher completely to the $10 \mathrm{~L}$ mark. Similar implementations were performed for Rhizo Vital 42, but this time $40 \mathrm{ml}$ Rhizo vital 42 was injected into $5 \mathrm{~L}$ of water and then completed to $10 \mathrm{~L}$. The prepared mixtures were applied weekly to each pot in $500 \mathrm{~mL}$ doses. Since the plants were smaller at the beginning of the experiment, the initial dose was arranged as $250 \mathrm{~mL}$ per plant for the first three treatments (Jezik et al., 2011). Specified doses of EM and Rhizo Vital 42 were applied weekly until the plant dry out date of $24^{\text {th }}$ August 2011. As soon as the plants started blooming, all the closed buds were harvested at a size of about $2 \mathrm{~cm}$, all the stamina were removed and the plain petals were stored in a deep freezer at $-21^{\circ} \mathrm{C}$. Harvesting was also stopped on $24^{\text {th }}$ August due to dry out of the plants.

The effects of Rhizo vital 42 and EM treatments on rooting were investigated as well. Plants were cut from the soil surface and the pots were emptied at the end of August 2011. A scale from 1 to 6 was formed to evaluate the root development (Table 1). In this way, the effects of treatments on root development were evaluated.

The root data were statistically analyzed by ANOVA and correlation analyses. SPSS 13.0 for Windows and LSD tests were also used for a mean separation.

Then the frozen petals were put in the refrigerator for a day for defrosting. After that, the photon measurements were made. For the measurements of the dissipation values, extracts had to be made with a juice separator (Multi-press automatic MP 80, BRAUN, Germany). After centrifuging and filtering, the extracts were ready for the measurements.

\section{Photoluminescence by Single Photon Counting}

From a biophysical point of view, electromagnetic interaction is dominant in biological systems and is described as thenon-equilibrium thermodynamic organization of biochemical substance (Feynman, 1985). Therefore, living systems emit and absorb electromagnetic fields called photons. This emission of the light fields of biosystems is known as "biophoton emission", sometimes called as "ultraweak bioluminescence".

Photoluminescence measurements were performed in 4 replications by using a single photon counting device (Photomultiplier Hamamatsu R 943-02, high voltage Tennelec TC 952, amplifier-discriminator HamamatsuC 3866, measuring card Tennelec Nucleus MCS II) developed at the Atomic Institute of the Technical University in Vienna Geissler (1999) now at the University of Natural Resources and Life Sciences, Vienna.

Measuring glasses were filled with $6 \mathrm{~g}$ of defrosted petals, which were radiated with the light of a quicksilverhigh-pressure-lamp (HOL-R delux, 80 watt, OSRAM, Germany) at a distance of $35 \mathrm{~cm}$ for $90 \mathrm{~s}$. Then the samples were put into the air-tight measuring chamber of the photon measuring arrangement. All this was executed under a rapid timetable. The photoluminescence of a sample was measured for $500 \mathrm{~s}$ in 4 replications. The integral photon emission with its special deviation kinematics was calculated and drawn by the software Origin Pro 8.0. Finally the amount of integral photon emission was interpreted with regard to internal quality: the lower the amount, the higher 
the quality.

In order to quantify different deviation kinematics, the declining curves were fitted by the double exponential function

$$
(y=A 1 \cdot \exp (-x / t 1)+A 2 \cdot \exp (-x / t 2)) .
$$

\section{Dissipation Value}

The dissipation value is used to interpret the energetic conditions of plants and can be calculated from $\mathrm{pH}$-value, electrical conductivity and redox potential (Velimirov, 2003). Therefore, the dissipation value is usually interpreted as follows: the lower it is the higher the energy potential and the more suitable it is for human nutrition (Zimmermann, 2003). In other words, smaller dissipation values indicate better qualities (Hoffmann, 2005). Only $10 \mathrm{~mL}$ petal solution (extract) could be extracted in the present study. However, about $30-40 \mathrm{~mL}$ extract is required for the measurements. Therefore $20 \mathrm{~mL}$ distilled water was added to complete the extract volume to $30 \mathrm{~mL}$. Then the electrochemical measurements of these sample solutions were performed by using the $\mathrm{pH}-$ Meter multi $340 \mathrm{i}$ from the WTW Company (Germany). The instrument features three electrodes, one to measure the redox potential and temperature (SenTixORP, WTW, Germany), one to measure the $\mathrm{pH}$ value and the temperature (SenTix 41, WTW, Germany) and one to measure the electrical conductivity (TetraCon 325, WTW, Germany). The $\mathrm{pH}$ electrode should initially be calibrated with the calibration solutions for $\mathrm{pH}$ values of 4.01 and 7 (by placing into buffer solutions with these $\mathrm{pH}$ values) and the conductivity electrode should be calibrated by placing in to $0.01 \mathrm{~mol} \mathrm{HCl}$ (hydrochloric acid). Before and after the calibrations, the electrodes were washed with distilled water and dried with fine paper towels. Then a magnetic stirrer was placed into each solution sample and placed over a magnetic field. Redox potential, $\mathrm{pH}$ value, electrical conductivity and temperature were measured simultaneously. The entire measurement data (180 values) were transferred into Excel. Then the dissipation values were calculated by using the following equation. The averages of the first and the last value of each parameter ( $\mathrm{pH}$-value, redox potential, electrical conductivity and temperature) were used to calculate the dissipation value. The electrical conductivity values were converted from $\mu \mathrm{S} / \mathrm{cm}$ to $\mathrm{mS} / \mathrm{cm}$. Then following equations was used:

\section{Dissipation value $[\mu \mathrm{W}]=\mathrm{Eh}^{2} / \Omega$}

Eh $=$ measured redox potential + electrodeconstant + temperature correction factor.

Temperature correction factor $=$ (measured temperature -25$) *(-0.71) \Omega=1 /(\mathrm{R} * 0.001)$

$\mathrm{rH}$ value $=\mathrm{Eh} /$ constant $+2 * \mathrm{pH}$

Where: $\mathrm{rH}=$ redox potential based on the $\mathrm{pH}$-value $\Omega=$ electrical resistance

Electrode constant $=207$ Constant $=29.07$ Eh $=$ redox potential $[\mathrm{mV}]$ - relative to the potential of the normal hydrogen electrode $\mathrm{R}=$ electrical conductivity $[\mathrm{mS} / \mathrm{cm}]$ $\mathrm{E}=$ redox potential $[\mathrm{mV}]$.

\section{Results}

\section{Integral Photon Emission of Photoluminescence}

Compared to control treatment, EM treatments reduced photon emission by $31.25 \%$ in 'Red Rocket', by $19.23 \%$ in 'Red Stone', by $16.33 \%$ in 'Orchid', $13.00 \%$ in 'White Rocket' and finally by $53.00 \%$ in 'Rocket Gold'. Rhizo vital 42 treatments decreased photon emissions by $68.75 \%$ in 'Red Rocket', 76.92\% in 'Red Stone', 73.33\% in 'Orchid', $77.22 \%$ in 'White Rocket' and $69.35 \%$ in 'Rocket Gold' variety. Such findings revealed that Rhizo vital 42 treatments improved petal quality much more than EM treatments (Fig. 1).

\section{Dissipation Value}

Through the application of EM and Rhizo Vital 42, positive results could be achieved in the varieties 'Orchid' and 'Red Rocket'. The dissipation values of the petals were significantly lower than those of the control. In this case, it is considered that these two varieties have a high energy potential and therefore have a high quality. In the varieties 'Golden' and 'Red Stone', only the Rhizo Vital 42 treatments could decrease the dissipation value of the petals and hence achieve a better quality. White Rocket could not be positively influenced by any of the treatments. On the contrary, the dissipation values of the petals were significantly higher than those of the control (Table 2).

Compared to the control, EM and Rhizo Vital 42 treatments caused significantly lower dissipation values in the leaves of all varieties, except 'White Rocket'. This represents a lower energy potential and consequently a lower quality for 'White Rocket' and the opposite for the other varieties. The most positive impacts of EM treatments on leaves were observed in 'Red Stone' with a value of 570 and most positive impacts of Rhizo vital 42 treatments were observed in 'Orchid' with a value of 554. The results revealed that Rhizo vital 42 has the most positive effects on the petals and leaves of 'Orchid' (Table 3).

\section{Effects of Rhizo Vital 42 and Effective Microorganisms on Rooting}

EM treatments had more positive impacts on root development than Rhizo Vital 42. The highest increase in rooting was found in 'White Rocket' treated with EM. However 'Orchid' treated with EM and 'White Rocket' treated with Rhizo vital 42 also showed a high increase. Also in 'Red Rocket' and 'Golden' treated with EM, the increase was high. Rhizo Vital 42 could not significantly increase the root development of 'Red Rocket' and 'Golden'. In 'Red Stone', neither of the two treatments could achieve better rooting (Table 4). 
Table 1: Scale for evaluating effects of Rhizo Vital 42 and Effective Microorganisms on root development

\begin{tabular}{ll}
\hline Scale number & Meaning \\
\hline 0 & no rooting \\
1 & little rooting \\
2 & slightly more rooting \\
3 & halfway rooted through \\
4 & lot of rooting \\
5 & very significant rooting \\
6 & completely rooted through \\
\hline
\end{tabular}

Table 2: Effects of treatments on dissipation of petals

\begin{tabular}{llll}
\hline \multicolumn{4}{c}{ Dissipation values [ $\mu \mathrm{W}]$} \\
\hline Variety & Control & EM & Rhizo Vital \\
\hline 'Red Rocket' (dark-red) & 426 & 344 & 380 \\
'Red Stone' (light-red) & 442 & 464 & 417 \\
'Orchid' (purple) & 502 & 443 & 373 \\
'White Rocket' (white) & 442 & 535 & 527 \\
'Golden' (yellow) & 513 & 588 & 462 \\
\hline
\end{tabular}

Table 3: Effects of treatments on dissipation of leaves

\begin{tabular}{llll}
\hline \multicolumn{4}{c}{ Dissipation values [ $\mu \mathrm{W}]$} \\
\hline Variety & Control & EM & Rhizo Vital \\
\hline 'Red Rocket' (dark-red) & 890 & 728 & 725 \\
'Red Stone' (light-red) & 850 & 570 & 669 \\
'Orchid' (purple) & 747 & 675 & 554 \\
'White Rocket' (white) & 610 & 621 & 697 \\
'Golden' (yellow) & 655 & 587 & 571 \\
\hline
\end{tabular}

the effects of EM treatments were found to be significant. Bajwa et al. (1999) reported that EM treatments increased the effects of vesicular arbuscular mycorrhizal fungi (VAM) colonization in chick pea (Cicer arietinum). Increased phosphorus and other nutrient uptakes through VAM colonization were also reported by other researchers (Graham and Menge, 1982; Smith et al., 1992). Kafkas and Ortaş (2009) indicated increased phosphorus uptakes of Pistacia species with VAM treatments. Various researchers indicated that phosphorus uptake improved the rooting (Lynch and Brown, 2001; Walk et al., 2006). Compared to control and Rhizo Vital 42 treatments, improved rooting with EM treatments of the present study supports the findings of previous studies. There is a certain level of microbial activity in soil, which is necessary for proper plant growth. Beside beneficial microorganisms, however, harmful microorganisms are also present in soils. Beneficial microorganisms inoculated into soils in order to remove the harmful ones from the soil and consequently reduce the stresses exerted on plants, increase internal quality and positively affect root development. The present study clearly indicated the positive impacts of Rhizo Vital 42 and EM treatments on plant root development and internal quality parameters. However, such positive impacts strictly depend on plant species, regional climate conditions, soil conditions, implementation doses and timing.

Table 4: Effects of Rhizo Vital 42 and Effective Microorganisms on rooting

\begin{tabular}{llllll}
\hline & \multicolumn{3}{c}{ Varieties } \\
\cline { 2 - 6 } Treatment & 'Red Rocket' (dark-red) & 'Red Stone' (light-red) & 'Orchid' (purple) & 'White Rocket' (white) & 'Golden' (yellow) \\
\hline Control & $1.79 \pm 1.23 \mathrm{abc}$ & $1.33 \pm 0.57 \mathrm{~cd}$ & $1.17 \pm 0.89 \mathrm{~d}$ & $1.58 \pm 1.16 \mathrm{bcd}$ & $1.38 \pm 0.53 \mathrm{~cd}$ \\
EM & $2.14 \pm 0.82 \mathrm{a}$ & $1.14 \pm 0.48 \mathrm{~d}$ & $1.61 \pm 0.48 \mathrm{bcd}$ & $2.13 \pm 0.84 \mathrm{a}$ & $1.76 \pm 0.57 \mathrm{abc}$ \\
Rhizo Vital 42 & $1.83 \pm 0.96 \mathrm{abc}$ & $1.21 \pm 0.43 \mathrm{~d}$ & $1.29 \pm 0.82 \mathrm{~d}$ & $2.04 \pm 0.97 \mathrm{ab}$ & $1.50 \pm 0.83 \mathrm{~cd}$ \\
\hline
\end{tabular}

Mean \pm standart deviation; Values indicated with different letters are significantly different $(\mathrm{P}<0.05)$

\section{Discussion}

Popp (1991) indicated that biophoton measurements could be used to assess bioenergetics status and tissues of plants. The researchers also indicated that the lower the biophoton emission, the higher the internal quality. Since Rhizo vital 42 and EM treatments decreased biophoton emissions, they improved internal quality (Fig. 1). Zimmerman (2003) indicated that the lower the p-dissipation value, the higher the energy potential will be thus more suitable for human nutrition. In another study, Hoffmann (2005) indicated lower P-dissipation values as the indicator of better quality. Compared to control treatment, Rhizo vital 42 and EM treatments generally decreased P-dissipation values of the petals and leaves (Tables 2 and 3). Such findings revealed the positive impacts of Rhizo Vital 42 and EM treatments on internal quality parameters.

The impacts of Rhizo vital 42 and EM treatments on root development were also investigated in this study and
Jezik et al. (2011) carried out a research on lettuce with organic fertilizers and observed $10 \%$ yield increase. It was concluded in this study that Rhizo Vital 42 and Effective Microorganisms could be used effectively as organic fertilizers in ornamental plant production. They may have positive impacts on inner quality parameters but the effects may vary based on species, varieties and treatments. Therefore, further research is needed on implementation doses and timing. Further research is also recommended to assess the impacts of such organic fertilizers on common vegetables. Since EM and Rhizo Vital 42 treatments do not have any proven negative impacts on soil and human health, further studies with other plants like vegetables should be conducted for sustainable agriculture.

\section{Acknowledgments}

The authors acknowledge YOK (The Council of Higher 


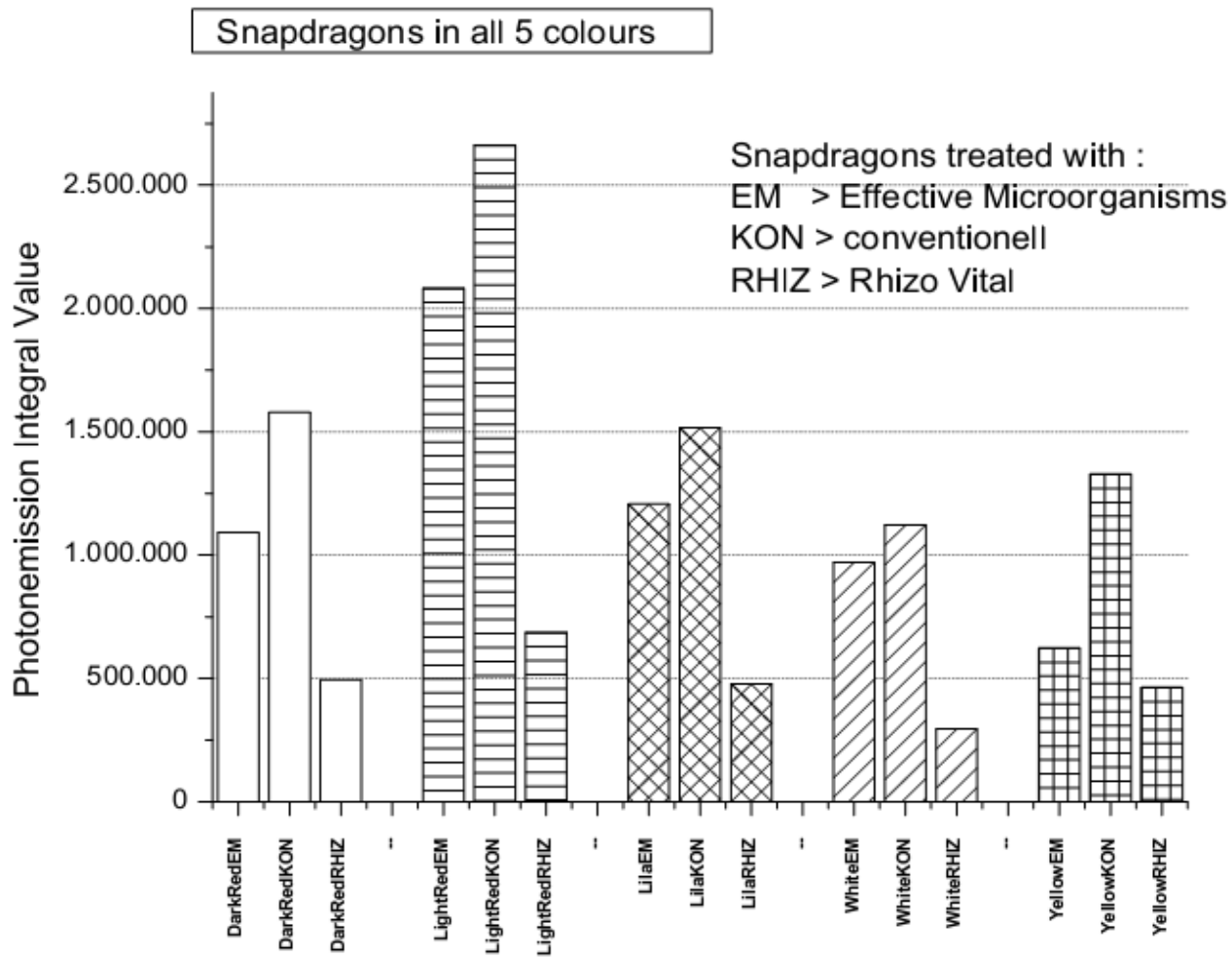

Fig. 1: Integral photon emission of photoluminescence of different varieties and treatments: the lower the amount, the higher the quality

Education), for the scholarship provided to M. Demirkaya and to Prof. Dr. Herbert Klima and DI. Dr. Alexander Geissler for explaining the photon measuring arrangements. The research activities were conducted at the University of Natural Resources and Applied Life Sciences, Vienna.

\section{References}

Bajwa, R., A. Javaid and B. Haneef, 1999. EM and VAM Technology in Pakistan V: Response of chickpea (Cicer arietinum L.) to coinoculation of effective microorganisms (EM) and VA mycorrhiza under allelopathic stress. Pak. J. Bot., 31: 387-396

Chen, X.H., J. Vater, J. Piel, P. Franke, R. Scholz, K. Schneider, A. Koumoutsi, G. Hitzeroth, N. Grammel, A.W. Strittmatter, G. Gottschalk, R.D. Süssmuth and R. Borriss, 2006. Structural and Functional Characterization of Three Polyketides Synthase Gene Clusters in Bacillus amyloliquefaciens FZB 42. J. Bacteriol., 188: 4024-4036

Chen, X.H., A. Koumoutsi, R. Scholz, A. Eisenreich, K. Schneider, I. Heinemeyer, B. Morgenstern, B. Voss, W.R. Hess, O. Reva, H. Junge, B. Voigt, P.R. Jungblut, J. Vater, R. Süessmuth, H. Liesegang, A. Strittmatter, G. Gottschalk and R. Borris, 2007. Comparative analysis of the complete genome sequence of the plant growth - promoting bacterium Bacillus amyloliquefaciens FZB42. Nat. Biol., 25: 1007-1014

Feynman, R.P., 1985. QED Quantum Electro Dynamic - The Strange theory of Light and Matter, $\mathrm{p}$; 158. Princeton University Press, Princeton. USA

Geissler, A., 1999. Diploma thesis, Technical University, Vienna, Austria Graham, J.H. and J.A. Menge, 1982. Influence of Vesicular- Arbuscular Mycorrhizae and Soil Phosphorus on Take - all Disease of Wheat. Phytopathology, 72: 95-98
Hoffmann, M., 2005. Lebensmittel und Ernährun gauselektrochemischer Sicht - Die bioelektronischen Zusammenhängezwischen Produktion, Qualität und Gesundheit von Lebensmitteln, $5^{\text {th }}$ edition. CO'MEDVerlag, Hochheim, Germany

Idriss, E.E., O. Makarewicz, A. Farouk, K. Rosner, R. Greiner, H. Bochow, T. Richter and R. Borris, 2002. Extracellular phytase activity of Bacillus amyloliquefaciens $\mathrm{FZB}_{45}$ contributes to its plant-growthpromoting effect. Microbiology, 148: 2097-2109

Jezik, K., W. Stumpf, P. Euteneuer, D. Ashebir and S. Ejaz, 2010. Summary and Comparison of Traditionally and Alternative Analyzing Methods to Measure the Quality of Apples: Results from 2009 and 2010. University of Natural Resources and Life Sciences, Vienna, Austria

Jezik, K., E. Gius, M. Eichinger, C. Huemer, K. Klopf, K. PalmetshoferGassner, T. Rössler, C. Sternecker and M. Weber, 2011. Anwendung von Pflanzenstärkungsmittel an Anthirrhinum im Freiland und deren Auswirkung auf die Qualität (holistische Qualitätsmethode) und das Pflanzenwachstum. Interdiszipliniertes Projekt aus Gartenbauwissenschaften. Endbericht Gartenbauprojekt. University of Natural Resources and Life Sciences, Vienna, Austria

Kafkas, S. and İ Ortas, 2009. Various mycorrhizal fungi enhance dry weights, P and Zn uptake of four Pistacia species. J. Plant. Nutr., 32: 146-159

Karakurt, H., R. Kotan, F. Dadasoglu, R. Aslantas and F. Sahin, 2011. Effects of plant growth promoting bacteria on fruit set, pomological and chemical characteristics, color values and vegetative growth of sour cherry (Prunus cerasus cv. Kutahya). Turk. J. Biol., 35: 283-291

Kilian, M. and G. Raupach, 1999. Bacillus subtilis als Pflanzenstärkungsmittelim Gemüsebau. Bayer AG, Leverkusen, Germany. Gemüse, 3: 160-163

Koumoutsi, A., X.H. Chen, A. Henne, H. Liesegang, G. Hitzeroth, P. Franke, J. Vater and R. Borriss, 2004. Structural and Functional Characterization of Gene Clusters Directing Nonribosomal Synthesis of Bioactive Cyclic Lipopeptides in Bacillus amyloliquefaciens FZB 42. J. Bacteriol., 186: 1084-1096 
Demirkaya et al. / Int. J. Agric. Biol., Vol. 18, No. 3, 2016

Lynch, J.P. and K.M. Brown, 2001. Topsoil foraging - an architectural adaptation of plants to low phosphorus availability. Plant Soil, 237: 225-237

Lorch, A., 2010. EM Eine Chance Für Unsere Erde - Effektive Mikroorganismen. Wirkungsweise und Praxis. Rub Graf-Lehmann, Bern, Germany

Priest, F.G., M. Goodfellow, L.A. Shute and R.C.W. Berkeley, 1987. Bacillus amyloliquefaciens sp. nov., nom. rev. Int. J. Syst. Bacteriol., 37: 69-71

Popp, F., 1991. Biophotonen-Analyse der Lebensmittelqualität. Verlag C.F. Müller, Karlsruhe, Germany
Schneider, K., X.H. Chen, J. Vater, P. Franke, G. Nicholson, R. Borriss and R.D. Süssmuth, 2007. Macrolactin is the Polyketide Biosynthesis Product of the pks2 Cluster of Bacillus amyloliquefaciens FZB42. J. Nat. Prod., 70: 1417-1423

Smith, S.E., A.D. Robson and L.K. Abott, 1992. The Involvement of Mycorrhizas in Assement of Genetically Dependent Efficiency of Nutrient Uptake and Use. Plant Soil, 146: 169-172

Walk, T.C., R. Jaramillo and J.P. Lynch, 2006. Architectural tradeoffs between adventitious and basal roots for phosphorus acquisition. Plant Soil, 279: 347-366

Zimmermann, R., 2003. Bestimmung der Wasserqualität Mittels Bioelektronischer Meßmethoden. Zimmerman Amino Comp Labors, Dettingen, Germany

(Received 01 June 2015; Accepted 26 October 2015) 